\title{
Photoacclimation in a tropical population of Cladophora glomerata (L.) Kützing 1843 (Chlorophyta) from southeastern Brazil
}

\author{
Bautista, AIN. and Necchi-Júnior, O.* \\ Departamento de Zoologia e Botânica, Universidade Estadual Paulista - UNESP, \\ Rua Cristóvão Colombo, 2265, CEP 15054-000, São José do Rio Preto, SP, Brazil \\ *e-mail: orlando@ibilce.unesp.br \\ Received October 13, 2005 - Accepted April 17, 2006 - Distributed February 29, 2008
}

(With 4 figures)

\begin{abstract}
Photoacclimation of photosynthesis was investigated in a tropical population of $C$. glomerata (São Paulo State, southeastern Brazil, $20^{\circ} 48^{\prime} 24^{\prime}$ S and $49^{\circ} 22^{\prime} 24^{\prime}$ ' W) by chlorophyll fluorescence parameters and chlorophyll a content. Plants were acclimated to two levels of irradiance: low $\left(65 \pm 5 \mu \mathrm{mol} . \mathrm{m}^{-2} \cdot \mathrm{s}^{-1}\right)$ and high $\left(300 \pm 10 \mu \mathrm{mol} . \mathrm{m}^{-2} . \mathrm{s}^{-1}\right)$ and $\mathrm{ex}-$ posed short-term (4 days) and long-term (28 days) under a light-dark cycle of 12:12 hours. Photosynthesis-irradiance (PI) curves revealed distinct strategies of photoacclimation. In long-term exposure, plants acclimated by altering the photosynthetic units (PSU) number and keeping fixed the PSU size, revealed by increased rates of maximum photosynthesis $\left(\mathrm{P}_{\max }\right)$, lower photosynthetic efficiency (alpha) and higher values of the saturation parameter $\left(\mathrm{I}_{\mathrm{k}}\right)$ under high irradiance. The short-term acclimation strategy consisted of changing the PSU size, with a fixed number of PSUs, as revealed by similar $\mathrm{P}_{\max }$ but higher alpha and lower $\mathrm{I}_{\mathrm{k}}$ under low irradiance. Chlorophyll a contents followed the general pattern reported in green algae of higher concentrations under lower irradiance. Dark/light induction curves revealed consistently higher values of potential quantum yield under low irradiance. Initial and final values showed a higher recovery capacity in the short $(84.4-90.6 \%)$ term exposure than in the long-term case (81.4-81.5\%). ETR (electron transport rate) and NPQ (non-photochemical quenching) values were consistently higher under low irradiance. ETR showed a continuous and steady increase along the light exposure period in the short and long-term experiments, whereas NPQ values revealed a rapid increase after 15 seconds of light exposure, kept a slightly increasing trend and stabilized in most treatments. Lower photosynthetic performance (ETR) and recovery capacity of potential quantum yield were observed, particularly in long-term exposure, suggesting that this population is constrained by the typical high light environment of tropical regions.
\end{abstract}

Keywords: acclimation, Cladophora, light, macroalgae, photosynthesis, tropical.

\section{Fotoaclimatação em uma população tropical de Cladophora glomerata (L.) Kützing 1843 (Chlorophyta) do sudeste do Brasil}

\section{Resumo}

A fotoaclimatação da fotossíntese foi investigada numa população tropical de Cladophora glomerata (Estado de São Paulo, sudeste do Brasil, $20^{\circ} 48^{\prime}$ 24" S e 49 22' 24" W) através de parâmetros de fluorescência da clorofila e conteúdo de clorofila a. As plantas foram aclimatadas a dois níveis de irradiância: baixa $\left(65 \pm 5 \mu \mathrm{mol} . \mathrm{m}^{-2} . \mathrm{s}^{-1}\right)$ e alta $\left(300 \pm 10: \mathrm{mol} \cdot \mathrm{m}^{-2} \cdot \mathrm{s}^{-1}\right)$ e expostas a curto período (4 dias) e longo período (28 dias) em fotoperíodo de 12 horas. Curvas de fotossíntese-irradiância (FI) revelaram estratégias distintas de fotoaclimatação. Plantas expostas a longo período aclimataram pela alteração do número de unidades fotossintéticas (UF) e mantiveram fixo o tamanho das UF. Estas características foram reveladas por menores taxas de fotossíntese máxima $\left(\mathrm{F}_{\max }\right)$, menor eficiência fotossintética (alfa) e valores mais altos do parâmetro de saturação $\left(\mathrm{I}_{\mathrm{k}}\right)$ em alta irradiância. A estratégia de aclimatação em curto período consistiu em mudança no tamanho das UF, com número fixo de UF, conforme revelado por taxas semelhantes de fotossíntese máxima $\left(\mathrm{F}_{\max }\right)$, maiores valores de alfa e menores de $\mathrm{I}_{\mathrm{k}}$ em baixa irradiância. Os conteúdos de clorofila a seguiram o padrão geral reportado para algas verdes de maiores concentrações em baixa irradiância. Curvas de indução escuro/luz revelaram valores consistentemente mais elevados de rendimento quântico potencial em baixa irradiância. Valores iniciais e finais mostraram capacidade de recuperação mais elevada em curto período (84,4-90,6\%) do que em longo período $(81,4-81,5 \%)$. Os valores da taxa de transporte de elétrons (ETR) e extinção não-fotoquímica (NPQ) foram consistentemente mais elevados em baixa irradiância. Os valores de ETR tiveram aumento contínuo e estável ao longo do período de exposição luminosa em curto e longo períodos, enquanto que os de NPQ revelaram aumento rápido após 15 seconds de exposição à luz, mantiveram leve tendência de aumento e então estabilizaram na maioria 
dos tratamentos. Performances fotossintéticas inferiores e menor capacidade de recuperação do rendimento quântico potencial foram observadas, sugerindo que esta população sofre inibições pelo típico ambiente de alta irradiância de regiões tropicais.

Palavras-chave: aclimatação, Cladophora, fotossíntese, luz, macroalga, tropical.

\section{Introduction}

The light regime is one of the major environmental factors controlling distribution and seasonality (Sheath, 1984), as well as the rate of photosynthesis in benthic algae (Hill, 1996). Considering that photosynthesis responds quantitatively to changes in light, environmental variation in its quantity and quality potentially accounts for much of the variation in the physiology, population growth, and community structure of benthic algae (Hill, 1996). Physiological acclimation to changes in light intensity and spectral quality is an important factor determining variations in photosynthetic responses and growth rates of algae in nature (Falkowski and LaRoche, 1991). Photoacclimation is here treated as a physiological process, i.e. phenotypic adjustments in response to variations of ambient light, in contrast to photoadaptation which refers to evolutional processes, i.e. changes in the genotype (Falkowski and La Roche, 1991).

Algae usually follows one of two basic photoacclimation strategies (Ramus, 1981; Falkowski and La Roche, 1991): one consists of an alteration in the size of photosynthetic units (PSU) and the other of changing the number of PSU. PSU is generally defined as the reaction center and its associated light-harvesting pigment complex (Ramus, 1981). It has been proposed that diatoms photoacclimate by altering the size of the PSUs, whereas chlorophytes alter the number of PSUs (Falkowski and Owens, 1980). However, both strategies can be found within algal groups (Perry et al., 1981; Falkowski et al., 1985) and even within a same species (Galagher et al., 1984). In addition, photoacclimation can occur by an adjustment of both number and size of PSUs in some species (Ramus, 1981; Vieira and Necchi, 2003).

Photoacclimation has been little documented in freshwater macroalgae. Kaczmarczyk and Sheath (1991) analysed the effect of light regime on the photosynthetic apparatus of the freshwater red alga Batrachospermumum boryanum Sirodot 1884 . Photosynthetic rates of plants grown under different wavelengths and irradiances did not differ significantly, and photosynthesis-irradiance (PI) curves for low and high light-acclimated field populations had similar saturation irradiance. Photoacclimation to underwater irradiance was experimentally evaluated in the charophyte Lamprothamnium papulosum (Küster et al., 2000) by chlorophyll fluorescence. Light saturation parameter $\left(I_{k}\right)$ and maximum photosynthetic rate $\left(\mathrm{P}_{\max }\right)$ increased, whereas photosynthetic efficiency $( \pm)$ became significantly lower with higher irradiances. Ensminger et al. (2001) studied the plasticity of photosynthesis in the green alga Cladophora glomerata from open and shaded sites by measurements of chlorophyll fluorescence, pigment composition and oxygen evolution. A higher capacity of thermal energy dissipation (as indicated by non-photochemical quenching, NPQ, parameter) and an increase in the total amount of xanthophyll-cycle pigments were found in plants from open sites. Acclimation to growth light conditions was also shown by experimental induction of NPQ, indicating higher increases in high-light plants.

Cladophora glomerata is one of the most widespread freshwater macroalgal species in the world (Dodds and Gudder, 1992; Sheath and Cole, 1992) and can be found almost throughout the year in shaded or open sites (Ensminger et al., 2000). However, it has not been found very often in tropical regions in Brazil (Necchi et al., 2000). Considering the paucity of information on photoacclimation of photosynthesis in freshwater macroalgae, and most particularly from tropical regions, this study was initiated. Photoacclimation of photosynthesis in a Brazilian population of $C$. glomerata from a tropical region was investigated by chlorophyll fluorescence parameters and chlorophyll a content.

\section{Material and Methods}

Samples from a population of $C$. glomerata were collected from a site in Rio Preto, near the Water Treatment Plant, São José do Rio Preto, São Paulo State, southeastern Brazil (20 48' $24^{\prime}$ ' S and $\left.49^{\circ} 22^{\prime} 24^{\prime \prime} \mathrm{W}\right)$. The site consists of an artificial concrete water channel flowing from the reservoir for water supply. Selected environmental characteristics at the time of collection are summarized in Table 1. Plants were cleaned of debris and visible epiphytes under a stereoscope and then transferred to an erlenmeyer with $250 \mathrm{~mL}$ of water from the collecting site, previously fil-

Table 1. Conditions in field or culture maintenance for the population of Cladophora glomerata tested for photoacclimation. Data are expressed as mean $\pm \mathrm{SD}(\mathrm{n}=10$ for irradiance and current velocity; $\mathrm{n}=3$ for temperature).

\begin{tabular}{|c|c|c|c|}
\hline Condition/dates & Temperature $\left({ }^{\circ} \mathbf{C}\right)$ & Irradiance $\left(: \mathrm{mol} \mathrm{m}^{-2} / \mathrm{s}\right)$ & Current velocity $(\mathrm{cm} / \mathrm{s})$ \\
\hline Field population & & & \\
\hline 21 August 2003 & $21.6 \pm 0.5$ & $1,370 \pm 140$ & $24 \pm 7$ \\
\hline Isolate in culture & & & \\
\hline September/October & $20.0 \pm 0.3$ & $300 \pm 10$ & - \\
\hline
\end{tabular}


tered and autoclaved. Plants were kept in laboratory conditions under controlled temperature and irradiance (Table 1) for two months to assure they were healthy and uncontaminated before initiating photoacclimation experiments.

Plants were acclimated to two levels of irradiance: low $\left(65 \pm 5 \mu \mathrm{mol} \cdot \mathrm{m}^{-2} \cdot \mathrm{s}^{-1}\right)$ and high $\left(300 \pm 10 \mu \mathrm{mol} \cdot \mathrm{m}^{-2} \cdot \mathrm{s}^{-1}\right)$. These two levels were used in a previous study (Zucchi and Necchi, 2001) and were shown to induce responses in growth and pigment content in freshwater red algae. In order to evaluate temporal variation in responses to photoacclimation, plants were exposed to the two levels of irradiance for a short-term (4 days) and long-term (28 days), both under a light-dark cycle of 12: 12 hours. The short-term Photoacclimation was established considering that the time required for photoacclimation in algae typically ranges from 13 to 100 hours (Falkowski and Raven, 1997).

Five replicates were used in experiments, each consisting of a culture tube $(25 \times 120 \mathrm{~mm})$ with $30 \mathrm{~mL}$ of water from the collecting site containing one plant (tuft) with initial fresh weights of $150 \pm 15 \mathrm{mg}$. The position of tubes within each set was changed at 5 day intervals to minimize irradiance differences among the replicates. Experiments were conducted at constant temperature $\left(20 \pm 0.3{ }^{\circ} \mathrm{C}\right)$ in a RI 12-555 Revco incubator with illumination from above supplied by two cool-white fluorescent lamps (Osram $15 \mathrm{~W}$ ). Irradiance reduction within the incubators was accomplished by using a neutral black mesh (50\% irradiance reduction). Underwater irradiance measurements were made with a Li-Cor LI189 quantameter (Li-Cor, Lincoln, NE, USA) coupled to a spherical quantum sensor LI-193 SA.

Measurements of photosynthetic parameters were performed by chlorophyll fluorescence using a Diving-PAM underwater fluorometer (Walz, Effeltrich, Germany). Algal thalli were placed directly on the tip of the fluorometer fiberoptic using the supplied magnet sample holder. Rapid light curves (White and Critchley, 1999) were generated and consisted of the fluorescence responses to eight increasing irradiance levels within the range of 0 to $690 \mu \mathrm{mol} \cdot \mathrm{m}^{-2} \cdot \mathrm{s}^{-1}$, using the "light curve" option of the Diving-PAM. The exposure time at each irradiance was $15 \mathrm{~s}$, each separated by a 0.8 seconds saturating flash $\left(\sim 6,000 \mu \mathrm{mol} . \mathrm{m}^{-2} \cdot \mathrm{s}^{-1}\right)$. The illumination periods of rapid light curves are too short to achieve true steady-states but provide sound information on the overall photosynthetic performance of a plant (White and Critchley, 1999). The Diving-PAM records all relevant fluorescence parameters, as well as actinic irradiance, and data were processed using the supplied WinControl software.

Four parameters were determined from each sample: 1) potential quantum yield of photosystem II, PSII $(\mathrm{Fv} / \mathrm{Fm})$, where $\mathrm{Fv}=$ variable fluorescence, $\mathrm{Fm}=$ maximal fluorescence of dark-adapted samples; for dark adaptation, apices of algal thalli were placed for $5 \mathrm{~min}$ utes (Ensminger et al., 2001) directly on the tip of the fiberoptic using the supplied dark leaf clip. 2) effective quantum yield of PSII ( $\Delta \mathrm{F} / \mathrm{Fm}$ '), where: $\Delta \mathrm{F}=\mathrm{Fm}$ ' $-\mathrm{Ft}$; Fm' - maximal fluorescence of an illuminated sample; Ft - transient fluorescence; 3) electron transport rate (ETR), calculated as $\Delta \mathrm{F} / \mathrm{Fm}$ ' $\mathrm{x}$ irradiance $\left(\mu \mathrm{mol} . \mathrm{m}^{-2} \cdot \mathrm{s}^{-1}\right)$; 4) non-photochemical quenching (NPQ), as a measure of heat dissipation of absorbed light energy, was calculated as: NPQ = Fm - Fm'/Fm'; Fm and Fm' (as explained above); NPQ was taken at the highest irradiance of the light curve $\left(690 \mu \mathrm{mol} . \mathrm{m}^{-2} . \mathrm{s}^{-1}\right)$. The calculations followed Schreiber et al. (1994) and Kromkamp et al. (1998), whereas the terminology described by van Kooten and Snel (1990) was adopted. PI curves were generated on the basis of ETR and the respective parameters were calculated by the equation of Jassby and Platt (1976): photosynthetic efficiency ( $\alpha$ ETR), maximum photosynthetic rate $\left(\mathrm{P}_{\max }=\mathrm{ETR}_{\max }\right)$ and saturation parameter $\left(\mathrm{I}_{\mathrm{k}}\right)$. The values of $\alpha$ ETR were determined by linear fitting using the three first points of the ETR versus irradiance curve (Necchi, 2004).

Dark/light induction (Kautsky) curves were performed on plants dark-adapted for 5 minutes. For dark adaptation, algal thalli were placed directly on the tip of the fibreoptic using the supplied dark leaf clip. First, a saturation pulse was applied for determination of potential quantum yield (as explained above). Then, a constant actinic irradiance $\left(405 \mu \mathrm{mol} . \mathrm{m}^{-2} . \mathrm{s}^{-1}\right)$ was applied using the halogen light source of the Diving-PAM with eight saturating light pulses given at 15 seconds intervals, initiated 30 seconds after the first saturation pulse. After recording of dark/light induction, six saturation pulses were applied at successive intervals (10, 30, 60 seconds and 2, 5 and 10 minutes) to assess the dark recovery of potential quantum yield.

After measurements of photosynthetic parameters, the five replicates were used for evaluation of chlorophyll a content. Plants were frozen for 7 to 15 days before chlorophyll quantification. Chlorophyll a was extracted in $90 \%$ alkaline acetone and quantified according to the spectrophotometric technique (Wetzel and Likens, 2000). Readings were made with a B 342-II Micronal spectrophotometer ( $1 \mathrm{~nm}$ resolution). Extractions and readings were conducted under dim light to avoid degradation.

Differences in means for photosynthetic parameters and chlorophyll a in the treatments of irradiance (low vs. high irradiance and short versus long-term) were tested by the Student $t$-test, whereas relationships among parameters were evaluated by the Pearson moment-product correlation coefficient (Zar, 1999). Statistical tests were performed by Statsoft Statistica 6.0 software, whereas graphs were made by Microcal Origin 5.0.

\section{Results}

\subsection{Photoacclimation based on PI curves and chlorophyll content}

Photosynthetic parameters for the short-term experiment showed significantly higher values of \pm and lower of $\mathrm{I}_{\mathrm{k}}$ under low irradiance, with similar values of $\mathrm{P}_{\text {max }}$ (Table 2, 

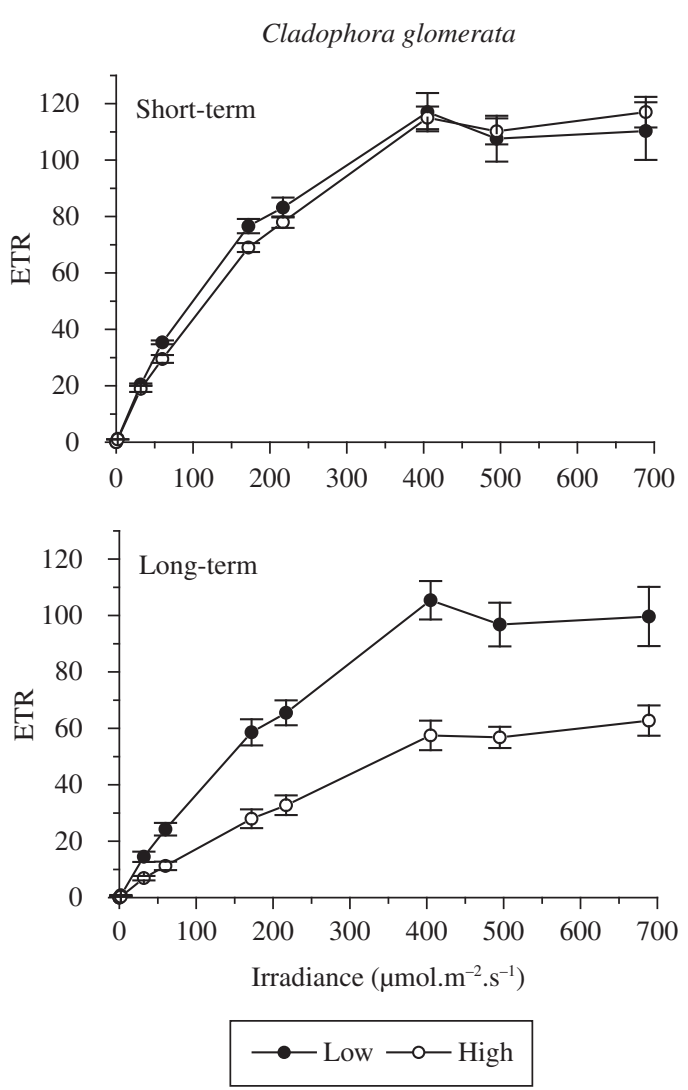

Figure 1. Photosynthesis-irradiance curves for the population of Cladophora glomerata under low $\left(65 \pm 5 \mu \mathrm{mol} . \mathrm{m}^{-2} . \mathrm{s}^{-1}\right)$ and high $\left(300 \pm 10: \mathrm{mol} \mathrm{m}^{-2} \cdot \mathrm{s}^{-1}\right)$ irradiances in short (4 days) and long-term (28 days) photoacclimation. Bars indicate $\mathrm{v} \pm$ $\mathrm{SD}(\mathrm{N}=5)$.
Figure 1). In addition, effective quantum yield was significantly higher, whereas NPQ was significantly lower under low irradiance. On the other hand, the long-term experiment revealed significantly higher values of of $\mathrm{P}_{\text {max }}$ and \pm and lower values of $I_{k}$ under low irradiance (Table 2, Figure 1). Effective quantum yield was significantly higher under low irradiance (Table 2), with more pronounced differences in the long-term experiment than in the short-term one (14 versus $42 \%)$. NPQ was consistently lower under low irradiance (20.5-22\%), but significantly different only in the short-term experiment (Table 2).

Chlorophyll a was consistently higher, but not significantly different, under low irradiance in both short

Table 3. Chlorophyll a content ( $\mu \mathrm{g} \mathrm{mg}^{-1}$ dry weight) of Cladophora glomerata under low $\left(65 \pm 5 \mu \mathrm{mol} . \mathrm{m}^{-2} . \mathrm{s}^{-1}\right)$ and high $\left(300 \pm 10 \mu \mathrm{mol} . \mathrm{m}^{-2} \cdot \mathrm{s}^{-1}\right)$ irradiances and short (4 days) and long-term (28 days) photoacclimation. Data are expressed as means \pm standard-deviations $(\mathrm{N}=5$, except if otherwise indicated). Distinct letters indicate significant differences $(\mathrm{p}<0.05)$ by Student's t-test.

\begin{tabular}{cc}
\hline Treatments & Chlorophyll content \\
\hline Short-term & $1.84 \pm 0.81$ (a) \\
Low irradiance & $1.32 \pm 0.74$ (a) \\
High irradiance & \\
Long-term & $0.92 \pm 0.46$ (a) \\
Low irradiance & $0.82 \pm 0.74$ (a) \\
High irradiance & $1.58 \pm 0.78$ (a) \\
Short-term* & $0.87 \pm 0.58(\mathrm{~b})$ \\
Long-term* &
\end{tabular}

Table 2. Parameters derived from the photosynthesis-irradiance curves for Cladophora glomerata tested under low $\left(65 \pm 5 \mu \mathrm{mol} \cdot \mathrm{m}^{-2} \cdot \mathrm{s}^{-1}\right)$ and high $\left(300 \pm 10 \mu \mathrm{mol} \cdot \mathrm{m}^{-2} \cdot \mathrm{s}^{-1}\right)$ irradiances in short (4 days) and long-term (28 days) photoacclimation. Data are expressed as means $\pm \mathrm{SD}(\mathrm{N}=5)$. Distinct letters indicate significant differences $(\mathrm{p}<0.05)$ by Student's $t$-test.

\begin{tabular}{|c|c|c|}
\hline \multirow[t]{2}{*}{ Parameter } & \multicolumn{2}{|c|}{ Irradiances } \\
\hline & Low & High \\
\hline \multicolumn{3}{|l|}{ Short-term } \\
\hline $\operatorname{Pmax}(E T R)$ & $114.5 \pm 4.9$ (a) & $116.4 \pm 3.3(\mathrm{a})$ \\
\hline Alpha (ETR) & $0.64 \pm 0.001(\mathrm{a})$ & $0.53 \pm 0.04(b)$ \\
\hline $\mathrm{I}_{\mathrm{k}}\left(: \mathrm{mol} \mathrm{m}^{-2} / \mathrm{s}\right)$ & $179.1 \pm 9.6(\mathrm{a})$ & $221.4 \pm 12.9(b)$ \\
\hline $\begin{array}{l}\text { Effective quantum yield } \\
\left(\Delta \mathrm{F} / \mathrm{F}_{\mathrm{m}}\right)\end{array}$ & $0.72 \pm 0.01$ (a) & $0.62 \pm 0.04(b)$ \\
\hline $\begin{array}{l}\text { Non-photochemical quenching } \\
\left(\mathrm{F}_{\mathrm{m}}-\mathrm{F}_{\mathrm{m}} / \mathrm{F}_{\mathrm{m}}\right)\end{array}$ & $1.01 \pm 0.12(\mathrm{a})$ & $1.27 \pm 0.20(\mathrm{~b})$ \\
\hline \multicolumn{3}{|l|}{ Long-term } \\
\hline Pmax (ETR) & $107.0 \pm 5.6(\mathrm{a})$ & $60.6 \pm 2.6(\mathrm{~b})$ \\
\hline Alpha (ETR) & $0.23 \pm 0.03$ (a) & $0.11 \pm 0.01(b)$ \\
\hline $\mathrm{I}_{\mathrm{k}}\left(: \mathrm{mol} \mathrm{m} \mathrm{m}^{-2} / \mathrm{s}\right)$ & $237.8 \pm 31.0(\mathrm{a})$ & $283.3 \pm 29.6(b)$ \\
\hline $\begin{array}{l}\text { Effective quantum yield } \\
\left(\Delta \mathrm{F} / \mathrm{F}_{\mathrm{m}}\right)\end{array}$ & $0.50 \pm 0.06(\mathrm{a})$ & $0.29 \pm 0.04(b)$ \\
\hline $\begin{array}{l}\text { Non-photochemical quenching } \\
\left(\mathrm{F}_{\mathrm{m}}-\mathrm{F}_{\mathrm{m}} / \mathrm{Fm}\right)\end{array}$ & $0.89 \pm 0.32(a)$ & $1.14 \pm 0.81(\mathrm{a})$ \\
\hline
\end{tabular}


and long-term experiments (Table 3). Combined results of low and high irradiances revealed significantly higher chlorophyll a content in the short-term experiment.

\subsection{Photoacclimation based on dark/light induction curves}

Dark/light induction curves for potential quantum yield (Figure 2) revealed similar patterns in short and long-term photoacclimation, with consistently higher, but not significantly different, values under low irradiance. Initial and final values showed a higher recovery capacity in the short term (84.4-90.6\%) than in the longterm $(81.4-81.5 \%)$ case. Values of potential quantum yield of low and high irradiances were positively correlated along the curve $(r=0.95-0.99, \mathrm{p}<0.001)$ in both the short and long-term exposure.

ETR values showed a continuous and steady increase along the light exposure period in short and longterm experiments, with consistently higher, not significantly different, values under low irradiance (Figure 3). ETR values were positively correlated along the curve

\section{Cladophora glomerata}
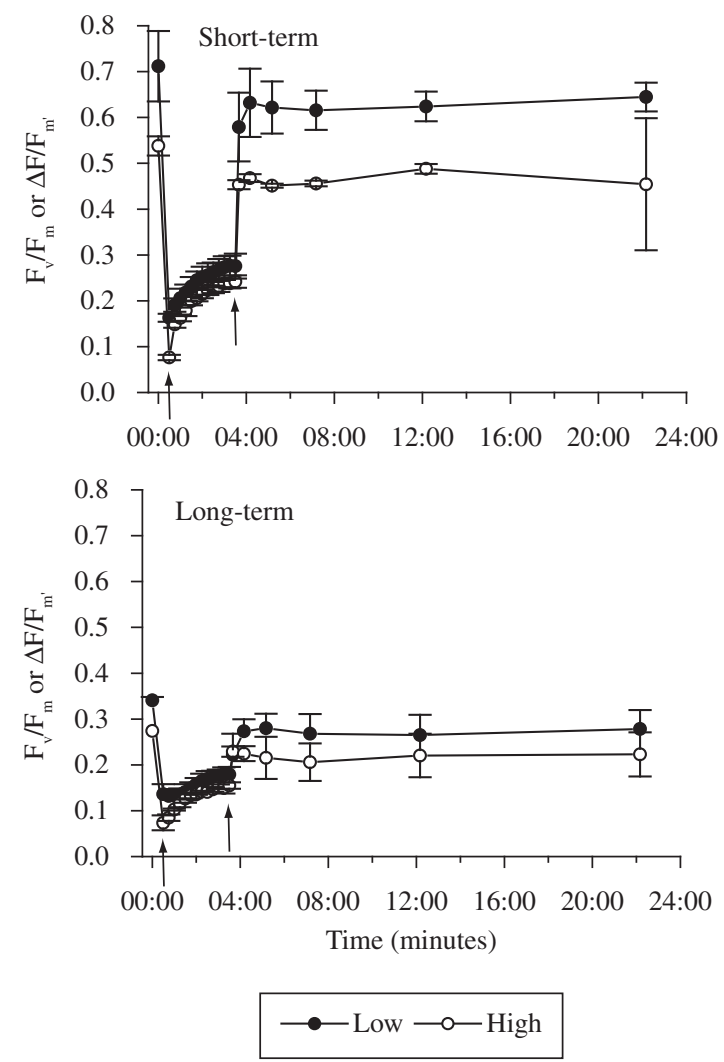

Figure 2. Dark/light (Kautsky) induction curves and recovery period of quantum yield for dark-adapted plants of Cladophora glomerata under low $\left(65 \pm 5 \mu \mathrm{mol} . \mathrm{m}^{-2} . \mathrm{s}^{-1}\right)$ and high $\left(300 \pm 10 \mu \mathrm{mol} . \mathrm{m}^{-2} \cdot \mathrm{s}^{-1}\right)$ irradiances in short (4 days) and long-term (28 days) photoacclimation. Arrows indicate the illumination period under constant irradiance $\left(405 \mu \mathrm{mol} \cdot \mathrm{m}^{-2} \cdot \mathrm{s}^{-1}\right)$. Bars indicate $\pm \mathrm{SD}(\mathrm{N}=5)$. $(r=0.97-0.99, p<0.001)$ in both the short and long-term experiments. NPQ values increased rapidly after $15 \mathrm{sec}-$ onds of light exposure, kept a slightly increasing trend up to 2 minutes 30 seconds and stabilized thereafter (Figure 4) in all treatments, except in short-term and high irradiance. In this treatment, a more rapid and higher increase occurred during the first 15 seconds and followed a decreasing trend after 30 seconds towards the end of the light exposure period. NPQ values were consistently higher under low irradiance in all treatments, except in short-term and high irradiance, in which this condition was reached only at the end of the light exposure period. However, NQP values under low and high irradiance were not significantly different and were positively correlated during the light period $(\mathrm{r}=0.85-0.99, \mathrm{p}<0.001)$ in both the short and long-term photoacclimation.

\section{Discussion}

PI curves revealed distinct strategies of photoacclimation in this tropical population of $C$. glomerata. In long-

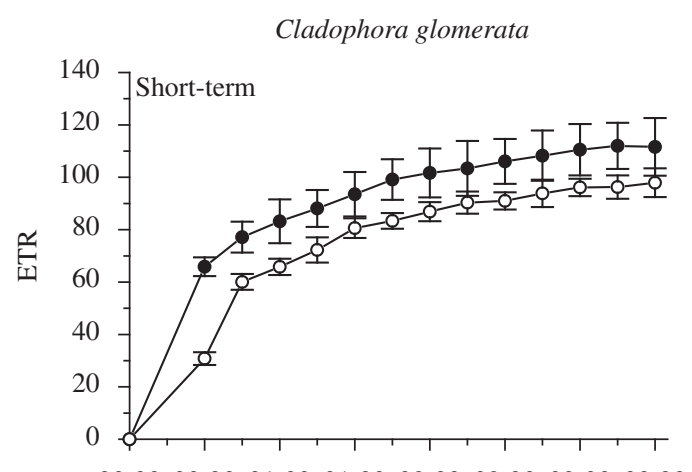

00:00 00:30 01:00 01:30 02:00 02:30 03:00 03:30

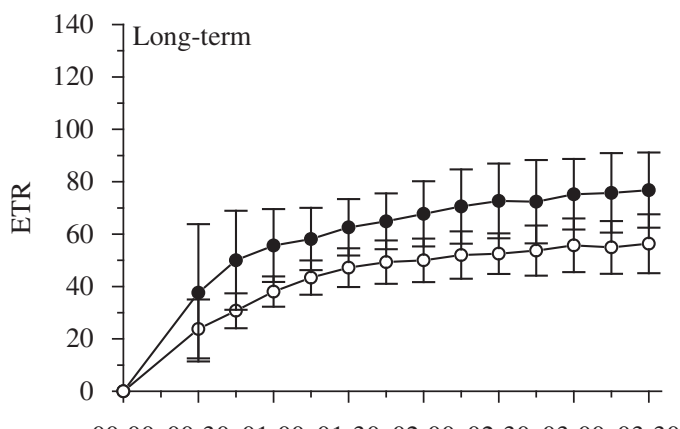

00:00 00:30 01:00 01:30 02:00 02:30 03:00 03:30

Time (minutes)

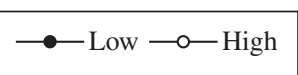

Figure 3. Dark/light (Kautsky) induction curves of electron transfer rate (ETR) for dark-adapted plants of Cladophora glomerata under low $\left(65 \pm 5 \mu \mathrm{mol} \cdot \mathrm{m}^{-2} \cdot \mathrm{s}^{-1}\right)$ and high $\left(300 \pm 10 \mu \mathrm{mol} \cdot \mathrm{m}^{-2} \cdot \mathrm{s}^{-1}\right)$ irradiances in short (4 days) and long-term (28 days) photoacclimation. The illumination period was under constant irradiance $\left(405 \mu \mathrm{mol} \cdot \mathrm{m}^{-2} \cdot \mathrm{s}^{-1}\right)$. Bars indicate $\pm \mathrm{SD}(\mathrm{N}=5)$. 

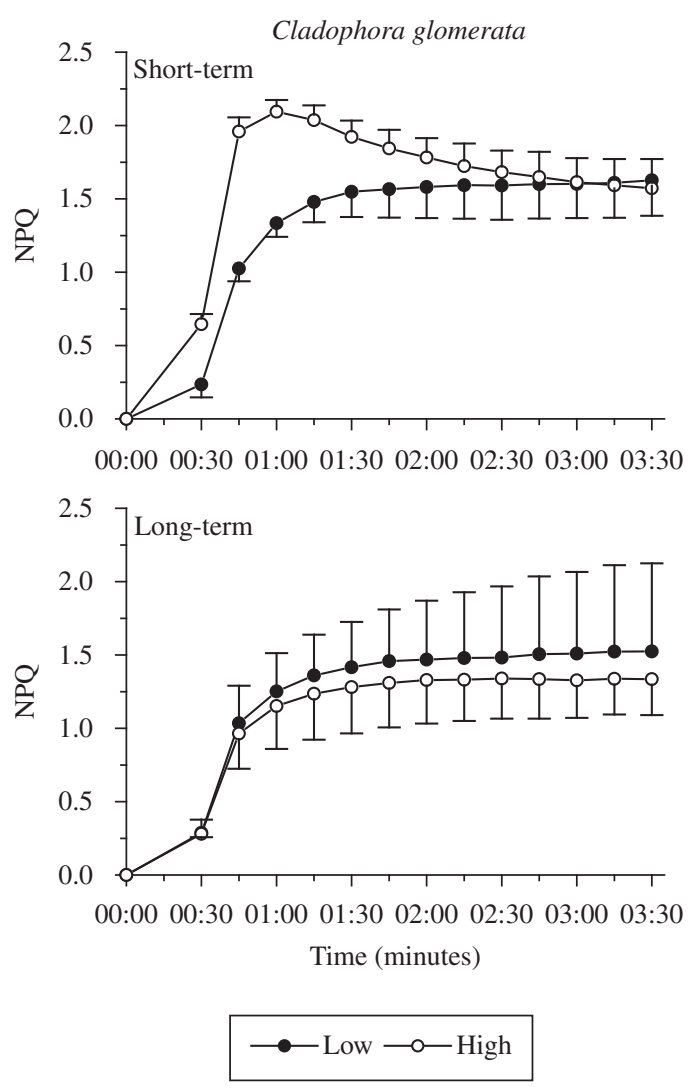

Figure 4. Dark/light (Kautsky) induction curves of nonphotochemical quenching (NPQ) for dark-adapted plants of Cladophora glomerata under low $\left(65 \pm 5 \mu \mathrm{mol} . \mathrm{m}^{-2} . \mathrm{s}^{-1}\right)$ and high $\left(300 \pm 10 \mu \mathrm{mol} . \mathrm{m}^{-2} \cdot \mathrm{s}^{-1}\right)$ irradiances in short (4 days) and long-term (28 days) photoacclimation. The illumination period was under constant irradiance $\left(405 \mu \mathrm{mol} \cdot \mathrm{m}^{-2} \cdot \mathrm{s}^{-1}\right)$. Bars indicate $\pm \mathrm{SD}(\mathrm{N}=5)$.

term exposure to distinct irradiances, plants acclimated by altering the PSUs number and keeping fixed the PSU size, revealed by decreased $\mathrm{P}_{\max }$, lower alpha and higher $\mathrm{I}_{\mathrm{k}}$ under high irradiance (Ramus, 1981). In this case, more light was needed to saturate photosynthesis (indicated by higher $\mathrm{I}_{\mathrm{k}}$ ). On the other hand, the acclimation strategy in the short-term experiment consisted of changing the PSU size, with fixed number of PSUs, as revealed by similar $\mathrm{P}_{\max }$ but higher alpha and lower $\mathrm{I}_{k}$ under low irradiance (Ramus, 1981). In this case, less light was required to saturate photosynthesis (lower $I_{k}$ ), i.e. PSUs were more efficient. Photoacclimation had a similar pattern in the charophyte Lamprothamnium papulosum (Küster et al., 2000) and in summer plants of a temperate population of $C$. glomerata (Ensminger et al., 2000), with increases in the saturation parameter $\left(\mathrm{I}_{\mathrm{k}}\right)$ and decreases of photosynthetic efficiency $( \pm)$ with higher irradiances. The only remarkable difference was the increase of $\mathrm{P}_{\max }$ with increasing irradiances in both studies with higher ETR values under high irradiances.

Ensminger et al. (2000) found that high-light plants (from open site) of C. glomerata collected in summer had higher $\mathrm{P}_{\max }$ than low-light (from shaded site) plants, whereas high and low-light plants collected in winter were sharply contrasted with similar values of $\mathrm{P}_{\max }$. Our results show a similar (short-term) or lower (longterm) values of $\mathrm{P}_{\max }$ when acclimated to high irradiance. The former were similar to winter plants in this respect, whereas the latter were different to the pattern described. The reason for these differences is presumably related to a mechanism of photoprotection of the photosystem from damage due to high irradiance, in this case a decrease of photosynthesis (photoinhibition). Nevertheless, the high irradiance treatment in this study can be considered low if compared to the ones experienced by the plants in their natural environment. This assumption is made considering the long-term exposure of this tropical population to high irradiances (monthly means 1,370-1,400 $\mu \mathrm{mol} \cdot \mathrm{m}^{-2} \cdot \mathrm{s}^{-1}$, Necchi, unpublished data), in contrast to more variable and lower values in temperate habitats, e.g. $<200-1,200 \mu \mathrm{mol} . \mathrm{m}^{-2} . \mathrm{s}^{-1}$ in open site (Ensminger et al., 2000, 2001). The dynamic control of photoinhibition has been proposed as a strategy of photoprotection against high irradiance in marine macroalge (Hanelt, 1996).

Chlorophyll a contents followed the general pattern of higher concentrations under lower irradiances and vice-versa, which is generally reported in green algae (Ensminger et al. 2000, 2001; Küster et al., 2000). Xanthophyll cycle pigments (not evaluated in this study) are also closely related to the light regime and have been typically reported to undergo increases under higher irradiances providing photoprotection to the photosynthetic apparatus in green algal species (Ensminger et al. 2000; 2001; Küster et al., 2000; Garcia-Mendoza et al., 2002).

A light-induced decrease of the effective quantum yield was observed in plants of $C$. glomerata by Ensminger et al. (2000) consisting of pronounced decreases with increased irradiance levels, but with higher decreases in low-light compared with high-light plants. These results are consistent with the acclimation pattern observed in this study, with lower values of effective quantum yield observed in plants acclimated to high irradiance, being higher in long-term compared with short-term (14 versus $42 \%$ ) exposure. In addition, results from dark/light induction curves revealed higher recovery capacity of potential quantum yield under low irradiance and short-term. These data are consistent with those described by Ensminger et al. (2001), who found a decreasing recovery capacity of potential quantum yield with increasing exposure duration to high irradiance using alternating sequences of high irradiances and subsequent recovery under dim-light conditions.

Ensminger et al. (2001) demonstrated that low and high-light plants of $C$. glomerata followed a saturation kinetic of NPQ when exposed to alternating sequences of high irradiances and dim-light conditions. The kinetics showed distinct differences of up and down-regulation of NPQ, with high-light plants having a faster and higher performance level of NPQ, whereas low-light 
plants had narrower and slower responses. Our results from dark/light induction curves revealed similar results only in short-term photoacclimation, although we found no significant differences between low and high irradiance, whereas a similar kinetics was found in long-term photoacclimation. NPQ values derived from PI curves showed a similar trend, with consistently higher values under high irradiances both in short and long-term. Garcia-Mendoza et al. (2002) also showed that NPQ followed the kinetics of the light supply mode, with highest values in high light cultures of the green alga Chlorella fusca Shihira et Krauss 1965. This pattern was proposed as an adequate photoprotective strategy of some green algae representing a possibility of fast responses to changes in irradiance.

Our results indicate different photoacclimation strategies to low and high irradiances in short and long-term photoacclimation. Garcia-Mendoza et al. (2002) showed that photoacclimation of Chlorella fusca was dependent from both intensity and periodicity of the light supply. They found that long-term acclimation was a slower process comprising regulation of the amount of the various components of the photosynthetic apparatus. On the other hand, fast short-term regulation involves photoprotective processes which are based on reversible changes in pools of existing molecules and variable assembly of supra-molecular complexes. Different acclimation processes occurred with respect to the reaction time needed until measurable effects could be distinguished, as well as the nature of these effects. This model presumably occurs in several algal species or groups and is perfectly applicable to the photoacclimation strategy of the $C$. glomerata population studied.

Some characteristics of photoacclimation in this population of $C$. glomerata suggest that it is constrained by the typical high light environment of tropical regions: 1) lower photosynthetic performances (lower ETR) under high irradiances both in PI and light/dark curves; 2) ower recovery capacity of potential quantum yield derived from light/dark curves. These characteristics are more evident in long-term exposures to high irradiance.

The mechanism described here allows the acclimation of the photosynthetic apparatus of the species studied to different habitat conditions, and might provide an important advantage compared to other species without such abilities and can explain its broad geographic distribution.

Acknowledgments - This research was supported by a FAPESP grant-in-aid (01/06139-3) to ONJ and CNPq grant and scholarship (520551/96-6). We are grateful to Maria Helena Carabolante for laboratory assistance.

\section{References}

DODDS, WK. and GUDDER, DA., 1992. The ecology of Cladophora in freshwaters. J. Phycol., vol. 28, no. 4, p. 415-427.

ENSMINGER, I., HAGEN, C. and BRAUNE, W., 2000. Strategies providing success in a variable habitat:
II. Ecophysiology of photosynthesis of Cladophora glomerata. Pl. Cell Environm., vol. 23, no. 10, p. 1129-1136.

ENSMINGER, I., XYLÄNDER, M., HAGEN, C. and BRAUNE, W., 2001. Strategies providing success in a variable habitat: III. Dynamic control of photosynthesis in Cladophora glomerata. Pl. Cell Environm., vol. 24, no. 8, p. 769-779.

FALKOWSKI, PG., DUBINSKY, Z. and WYMAN, J., 1985. Growth-irradiance relationships in marine phytoplankton. Limnol. Oceanogr., vol. 30, no. 2, p. 311-321.

FALKOWSKI, PG. and LAROCHE, J., 1991. Acclimation to spectral irradiance in algae. J. Phycol., vol. 27, no. 1, p. 8-14.

FALKOWSKI, PG. and OWENS, TG., 1980. Light-shade adaptation: two strategies in marine phytoplankton. Pl. Physiol., vol. 66 , no. 4, p. 592-595.

FALKOWSKI, PG. and RAVEN, JA., 1997. Aquatic photosynthesis. Blackwell Sci., Malden, $375 \mathrm{p}$.

GALLAGHER, JC., WOOD, AM. and ALBERTE, RS., 1984. Ecotypic differentiation in the marine diatom Skeletonema costatum: influence of light intensity on the photosynthetic apparatus. Mar. Biol. (Berl.), vol. 82, no. 2, p. 121-134.

GARCIA-MENDOZA, E., MATTHIJS, HCP., SCHUBERT, H. and MUR, LC., 2002. Non-photochemical quenching of chlorophyll fluorescence in Chlorella fusca acclimated to constant and dynamic light conditions. Photosynth. Res., vol. 74, no. 3, p. 303-315.

HANELT, D. 1996. Photoinhibition of photosynthesis in marine macroalgae. Sci. Mar., vol. 60, suppl. 1, p. 243-248.

HILL, WR. 1996., Effects of light. In STEVENSON, RJ., BOTHWELL, ML. and LOWE, RL. (eds.), Algal ecology: freshwater benthic ecosystems. Academic Press, San Diego, p. 121-148.

JASSBY, AD. and PLATT, T., 1976. Mathematical formulation of the relationship between photosynthesis and light for phytoplankton. Limnol. Oceanogr, vol. 21, no. 4, p. 540-547.

KACZMARCZYK, D. and SHEATH, R.G., 1991. The effect of light regime on the photosynthetic apparatus of the freshwater red alga Batrachospermum boryanum. - Cryptogam., Algol., vol. 12 , no. 4 , p. $249-263$.

KROMKAMP, J., BARRANGUET, C. and PEENE, J., 1998. Determination of microphytobenthos PSII quantum efficiency and photosynthetic activity by means of variable chlorophyll fluorescence. Mar. Ecol. Progr. Ser., vol. 162, p. 45-55.

KÜSTER, A., SCHAIBLE, R. and SCHUBERT, H., 2000. Light acclimation of the charophyte Lamprothamnium papulosum. Aquat. Bot., vol. 68, no. 3, p. 205-216.

NECCHI, O. Jr., 2004. Light-related photosynthetic characteristics of lotic macroalgae. Hydrobiologia, vol. 525, no. 1-3, p. 139-155.

NECCHI, O. Jr., BRANCO, CCZ. and BRANCO, LHZ., 2000. Distribution of stream macroalgae in São Paulo State, southeastern Brazil. Algolog. Stud., vol. 97, p. 43-57.

PERRY, M., TALBOT, M. and ALBERTE, R., 1981. Photoadaptation in marine phytoplankton: response of the photosynthetic unit. Mar. Biol. (Berl.), vol. 62, no. 2-3, p. 91-101.

RAMUS, J., 1981. The capture and transduction of light energy. In LOBBAN, CS. and WYNNE, MJ. (eds.), The biology of seaweeds. Blackwell Sci., Oxford, p. 458-492. 
SCHREIBER, U., BILGER, W. and NEUBAUER, C., 1994. Chlorophyll fluorescence as a non-intrusive indicator for rapid assessment of in vivo photosynthesis. In: E-D.Schulze and M.M. Caldwell (eds.), Ecophysiology of photosynthesis. SpringerVerlag, Berlim, p. 49-70.

SHEATH, RG. 1984., The biology of freshwater red algae. In Round, FE. and Chapman, DJ. (eds.), Progress in Phycological Research, vol. 3, p. 89-157 Biopress, Bristol.

SHEATH, RG. and COLE, KM., 1992. Biogeography of stream macroalgae in North America. J. Phycol., vol. 28, no. 4, p. $448-460$.

VAN KOOTEN, O. and SNEL, JJH. 1990. The use of chlorophyll fluorescence nomenclature in plant stress physiology. Photosynth. Res., vol. 25, no. 3, p. 147-150.
VIEIRA, JJR. and NECCHI-Jr, O., 2003. Photosynthetic characteristics of charophytes from tropical ecosystems. Phycolog. Res., vol. 51, no. 1, p. 51-60.

WETZEL, RG. and LIKENS, GE., 2000. Limnological analyses, $3^{\text {rd }}$ edition. Springer-Verlag, New York, 429 p.

WHITE, AJ. and CRITCHLEY, C., 1999. Rapid light curves: a new fluorescence method to assess the state of the photosynthetic apparatus. Photosynth. Res., vol. 59, no. 1, p. 63-72.

ZAR, J.H. 1999. Biostatistical Analysis. $4^{\text {th }}$ ed. Prentice Hall, New Jersey, 663 p.

ZUCCHI, MR. and NECCHI-Jr, O., 2001. Effects of temperature, irradiance and photoperiod on growth and pigment content in some freshwater red algae in culture. Phycolog. Res., vol. 49, no. 2, p. 103-114. 